Working Paper No. 640, 2005

\title{
Factor Supplies and the Direction of Technical Change
}

by Helena Svaleryd and Jonas Vlachos

IUI, The Research Institute of Industrial Economics

P.O. Box 5501

SE-114 85 Stockholm

Sweden 


\title{
Factor supplies and the direction of technical change
}

\author{
Helena Svaleryd ${ }^{*}$ and Jonas Vlachos ${ }^{* *}$
}

\begin{abstract}
In this paper, we empirically address the hypothesis that there is a relationship between the supply of human capital and the rate and direction of skill-biased technical change (SBTC). Using country- and industry-level data on OECD countries, we find R\&D to be positively related to the supply of human capital. There is, however, no indication that this translates into higher rates of SBTC, when SBTC is measured as changes in the wage bill share of skilled labor. Interestingly, both R\&D and the rate of SBTC seem to be relatively high in low-skill industries in countries where the supply of human capital is relatively high.
\end{abstract}

Keywords: Skill-biased technical change; Supply of human capital JEL classification: J31; O31

\footnotetext{
- We are grateful for helpful comments and advice from Daron Acemoglu and Matthew Slaughter. This paper was partly written while Vlachos was visiting the Graduate School of Business at University of Chicago. Financial support from Jan Wallander's and Tom Hedelius' Research Foundation is gratefully acknowledged.

* The Research Institute of Industrial Economics, P.O. Box 5501, 11485 Stockholm, Sweden. E-mail helenas@iui.se. Phone: +46-8-6654529. Fax +46-8-6654599.

** The Research Institute of Industrial Economics and CEPR, P.O. Box 5501, 11485 Stockholm Sweden. Email jonas.vlachos@iui.se.
} 


\section{Introduction}

There is now widespread academic agreement that technical change has been skill-biased during the post-war period. ${ }^{1}$ This conclusion is drawn from the observation that the college wage premium has gone up, even while the supply of college graduates has increased substantially. The pattern of skill-biased technical change (SBTC) has not been uniform across countries, however. ${ }^{2}$ To explain these differences, Acemoglu (2002b) presents a model suggesting that the diverging patterns could be caused by the endogenous response of technical change to the supply of skilled labor. In this model, an increase in the supply of skills can generate SBTC, because profit-motivated innovators benefit from serving a larger market. Here, we empirically investigate the relationship between the supply of human capital and SBTC by studying a group of OECD countries.

If the mechanisms highlighted by Acemoglu are important determinants of cross-country differences in SBTC, we expect SBTC to be higher in countries with a large supply of skilled labor. We calculate direct measures of SBTC based on the skilled-worker share of the wage bill. Using these measures, we find no support for the hypothesis that the rate of SBTC is related to the supply of human capital. Moreover, we study the impact of the supply of human capital on R\&D spending and find results indicating that human capital has a positive impact on industry $R \& D$ intensity. To the extent that $R \& D$ proxy for SBTC (Autor, Katz and Kreuger, 1998, Machin and Van Reenen, 1998), this result lends support to the hypotheses.

We further explore the possible impact of the supply of human capital on SBTC by studying industry-level data. This allows us to study both the average impact of human capital on SBTC and the potential sector bias of SBTC. That the latter can be of

\footnotetext{
${ }^{1}$ For a survey on the impact of skill biased technical change on wage differentials, see Katz and Autor (2000). Card and DiNardo (2002) present a dissenting view by arguing that the pattern of the skill premium is not consistent with any simple version of the SBTC hypothesis. Especially, they are critical of the link between computer use and SBTC. For a survey on endogenous technical change and its impact on the labor market, see Acemoglu (2002a).

${ }^{2}$ Gottschalk and Smeeding (1997) document differences in skill premia across different developed economies. Acemoglu (2003) finds that these differences to some extent reflect different rates of SBTC across countries.
} 
importance is shown by Haskel and Slaughter (2002) who find that in periods when SBTC is biased towards high-skill industries, wage inequalities tend to increase. Our results show that both SBTC and R\&D are relatively high in low-skill industries in countries with a relatively large supply of human capital during the 1980's.

Some previous results in the literature are interesting in the light of our findings. Using US data, Lawrence and Slaughter (1993) find that productivity growth was relatively high in low-skilled sectors during the 1980's. They suggest that trade may have caused this pattern. Our results suggest that this effect could be due to the relatively high rate of SBTC in low-skill industries experienced by countries with a large supply of human capital during the 1980 's.

The plan of the paper is as follows. The next section explains more in detail why the supply of human capital might affect country SBTC. Section 3 lays out the empirical strategy and Section 4 discusses measurement issues and the data. The results are presented in Section 5 and a concluding discussion can be found in Section 6 .

\section{Effects of the supply of human capital on SBTC}

Acemoglu (2002b) develops a theory where SBTC is caused by an increase in the supply of skills. In his model, the development and adaptation of new technologies are endogenously determined by profit-motivated firms, which can develop technologies complementing the various factors of production to different degrees. Depending on the relative profitability of different types of innovations, technical change will be biased towards the most profitable production factor.

An increase in the supply of skills has two opposing effects in this model. First, it reduces the relative price of skilled labor. This price effect yields a technical bias favoring the relatively scarce factor of production, i.e. unskilled labor in this case. This mechanism goes back to Hicks (1932), who argues that technical change favors the relatively 
expensive factor. ${ }^{3}$ Second, the increased supply of skills increases the market for innovations enhancing skilled labor. This market size effect tends to encourage technical change in favor of the factor with a large market. Thus, if there is an increase in the share of skilled in the labor force, this could generate SBTC. It turns out that the second effect dominates the first if the elasticity of substitution between production factors is sufficiently large. Accordingly, an increased supply of skilled labor will lead to an increase in the rate of SBTC, if the elasticity of substitution between skilled and unskilled labor is large. Several studies that have investigated this elasticity have indeed found it to be sufficiently large to generate these effects. ${ }^{4}$

Some caveats are worth mentioning, especially in relation to Acemoglu's framework. Here, we interpret his model quite literally. In reality, the relevant market size for innovations is hard to define. It is, for example, possible that skill-enhancing innovations developed in a skill-abundant country are also put to use in countries where skilled labor is relatively scarce. For this reason, it might be the case that the relevant market for innovations is the whole world, which would make cross-country comparisons meaningless. International trade is another complicating issue since it affects factor prices - a central mechanism in Acemoglu's model. Thus, if we fail to find a relationship between the supply of human capital and SBTC, this is not necessarily an indication that the theory is inconsistent with the data. It does, however, imply that the cross-country differences in the supply of human capital cannot explain the differences in the patterns of SBTC experienced by the industrial world in the post-war period.

To further our understanding of a link between the supply of human capital and SBTC, we also study the industry pattern of SBTC. It is plausible that technological progress causes the productivity of high skilled relative to low skilled workers to increase more quickly in some industries than in others. If, for example, industries with a large share of

\footnotetext{
${ }^{3}$ This is also known as the induced innovation hypothesis. Other important contributions in this area are Habakkuk (1962), who argues that higher wages induce firms to adopt labor saving technologies, and Kennedy (1964) who highlights the trade-off between different technologies along an "innovation possibilities frontier". Vernon Ruttan, another pioneer in this field with a special emphasis on the experience of developing countries, summarizes his views in Ruttan (2001).

${ }^{4}$ On the estimated size of this elasticity, see Freeman (1986). See also the references in Acemoglu (2002b).
} 
skilled workers experience a relatively high productivity increase for these workers, SBTC would be biased towards skill-intensive sectors of the economy. ${ }^{5}$ That such sector biases can be of importance is shown by Haskel and Slaughter (2002) who find that in periods when SBTC is biased towards high-skill industries, wage inequalities tend to increase. However, they do not provide an explanation for the sector biases they document.

Other theories of endogenous technical change might potentially explain the different patterns across countries. In the model developed by Thoenig and Verdier (2003), globalization triggers an increased threat of technical imitation that causes firms to develop skilled labor intensive technology. The process of defensive skill-biased innovation generates an increase in wage inequality. Other evidence of a trade effect is presented in Maurin, Thesmer and Thoenig (2002). In their study of firm-level data, larger exports create a greater demand for skills. We do not directly attempt to evaluate these theories, but we do control for the effects of international trade on technical change.

\section{Empirical strategy}

\subsection{Aggregated SBTC}

We perform a very simple and straightforward test of the hypothesis that the supply of human capital has an effect on the rate of SBTC. We estimate the following relation:

(3.1) $\mathrm{SBTC}_{j t}=\alpha_{1} \mathrm{HC}_{j t}+\alpha_{2} \mathrm{X}_{j t}+\varepsilon_{j t}$,

where $\mathrm{SBTC}_{j t}$ is the rate of $\mathrm{SBTC}$ in country $j$ from time $t$ and onwards, $\mathrm{HC}_{j t}$ is the supply of human capital in country $j$ at time $t, \mathrm{X}_{j t}$ are control variables and $\varepsilon_{j t}$ is the usual

\footnotetext{
${ }^{5}$ Note that Acemoglu's model does not differentiate between sector bias (between different sectors of the economy) and factor bias (between different factors of production). Rather, the two-sector model he considers only has one sector using skilled labor while the other uses only unskilled labor.
} 
error term. If $\alpha_{1}>0$, the rate of SBTC is relatively high in countries with a large supply of human capital.

\subsection{Sector biases of SBTC}

To investigate the effects of human capital on the industry pattern of SBTC, we allow for different effects in high-skill and low-skill industries. We evaluate the relation between supply of human capital and the level and direction of SBTC to estimate the following:

$$
\begin{aligned}
\mathrm{SBTC}_{i j t} & =\alpha_{1} \mathrm{HC}_{j t}+\alpha_{2} \text { Skillint }_{i j t}+\alpha_{3} \mathrm{HC}_{j t} \times \mathrm{Skillint}_{i j t}+\alpha_{4} \mathrm{X}_{j t}+\alpha_{4} \mathrm{Z}_{i t} \\
& +\alpha_{5} \mathrm{~S}_{i j t}+\varepsilon_{i j t} .
\end{aligned}
$$

$\mathrm{SBTC}_{i j t}$ is the country-industry indicator of SBTC for each time period and $\mathrm{HC}_{j t}$ is the beginning-of-the-period measure of country-level supply of human capital. Skillint ${ }_{i j t}$ is the beginning-of-the period measure of industry-level skill intensity and $\mathrm{HC}_{j t} \times \mathrm{Skillint}_{i j t}$ is the interaction between these two. $\mathrm{X}_{j t}$ is a vector of country level, $\mathrm{Z}_{i t}$ of industry level, and $\mathrm{S}_{i j t}$ of country-industry control variables. Finally, $\varepsilon_{i j t}$ is an error term. We make different assumptions concerning the error term and use a specification comprised of industry, country, country-industry, and time fixed effects. Since the level of aggregation is different for the dependent and some of the explanatory variables, we cluster the standard errors at the country (or country-year) level.

If $\alpha_{1}>0$, the implication is that countries with a well-educated population experience more rapid SBTC on average. If $\alpha_{2}>0$, the implication is that, on average, SBTC is more pronounced in skill-intensive industries, while $\alpha_{3}>0$ implies that SBTC is especially rapid in skill-intensive industries in countries where the population is well educated.

\section{Measurement and data}

\subsection{Measurement}


Our main measure of SBTC is the change in the share of skilled workers' wage bill, $\Delta \omega_{i j t}$, where subscript $i$ indicates industry, $j$ country, and $t$ time period. If this share increases when accounting for changes in the relative wage rates of skilled to unskilled workers, this means that the demand for skilled labor has increased. Such an increase in relative demand is commonly used to measure the degree of SBTC. ${ }^{6}$

This measure of SBTC is calculated at the industry level and then also aggregated to cover the whole manufacturing sector. We use the aggregated measure as an indicator of the degree of economy wide SBTC.

The measure of SBTC described above has the drawback of being based on an explicit functional form of the production function. Our second strategy is therefore to use R\&D spending (as a share of production) as a proxy for SBTC since Machin and Van Reenen (1998) show that $R \& D$ is closely related to the growth in importance of highly skilled workers. Is it a reasonable indicator? Admittedly, no single proxy for technology is perfect. However, R\&D has several advantages as compared to other measures. Unlike data on investments in computers and information technology, or data on innovation such as patent counts, data on R\&D is broadly comparable across industries, countries and time. Moreover, studies have shown R\&D expenditure to be an acceptable proxy for the outputs of the innovation process (see, for example, Griliches, Hall and Pakes, 1991).

We study effects of the supply of human capital on the R\&D intensity within industries. It is not possible to study the impact on the aggregated manufacturing sector, since we would then mostly pick up changes in size of different sectors within manufacturing. Thus, it is obvious that growth in supply of human capital should result in growth of $R \& D$ intensive sectors. The question we ask in this paper is whether a larger stock of

\footnotetext{
${ }^{6}$ This is based on Binswanger (1974) and Berndt and Wood (1982). That $\Delta \omega_{i j t}$ corresponds to changes in the relative demand for skilled labor is based on an assumption of a translog cost function with CRS at the industry level. Due to data limitations, we do not control for changes in the capital stock. This amounts to an assumption that there are no complementarities between capital and skilled or unskilled labor. We have also run regressions without controlling for changes in the relative wage rate, which allows for the possibility that the variation in cross-industry wage changes is due to unobserved changes in the skill intensity. The results essentially remain unchanged.
} 
human capital results in relatively more $R \& D$ in a particular industry. Since R\&D spending is a proxy for subsequent technical change, we will use the level of $R \& D$ rather than the changes in this variable. To account for dynamics, $R \& D$ will be regressed on both contemporaneous and lagged levels of human capital, as well as changes in human capital.

One question that arises is whether an increase in the supply of human capital is merely a response to the introduction of skill-biased technologies. In other words, is there a case of reverse causality? Several studies of SBTC suggest that skill upgrading occurs after the introduction of new technology (see, for example, Author, Katz and Krueger, 1998, and Machin and Van Reenen, 1998). By studying the levels and changes of human capital in previous periods, we limit the endogeneity problem. Moreover, Doms, Dunne and Troske (1997) find that causality runs in the direction suggested in this study. When studying firm-level data, they find that plants adopting new factory automation technologies have more skilled workforces both pre- and post adoption.

\subsection{Data}

To calculate the wage based measures of SBTC, we make use of the United Nations General Industrial Data Base (UNIDO) on industrial output and composition. Up until the early 1990's, this database reported the number and wage bills of production and nonproduction workers, respectively. Several researchers have shown that this classification closely follows the skill intensity of an industry (see, for example, Berman, Bound and Machin, 1998). Here, we follow the earlier literature and define non-production workers as skilled and production workers as unskilled. All in all we have, depending on decade, data on up to 14 countries. ${ }^{7}$ The SBTC measure is calculated for two decades, the 1970's and the 1980's. For R\&D expenditures, we employ data collected by the OECD. The Business Enterprise R\&D (ANBERD) data base contains information for 14 countries

\footnotetext{
${ }^{7}$ Australia, Austria, Belgium, Canada, Denmark, Finland, Greece, Japan, Norway, Portugal, Sweden, UK, USA and West Germany in the 1970's. In the 1980's, Spain is included rather than Norway.
} 
over the period $1973-1998 .{ }^{8}$ Industry R\&D intensity is expressed as the ratio between $R \& D$ expenditure and total production.

As a proxy for the country stock of human capital, we use total years of schooling (or the years of higher education) in the population above 25 from the Barro-Lee (2000) data set on human capital. When so needed, the data has been annualized using simple interpolation.

When using our direct measure of SBTC, we define skill intensity as the number of nonproduction workers divided by the number of production workers. When we apply our indirect measure, R\&D intensity, we construct a measure of skill intensity using US data from the Current Population Survey (CPS). Assuming industry skill intensities to be constant across countries, we construct industry-level indicators of educational attainment by defining skill intensity as the share of people employed with at least some college education. ${ }^{9}$ Since skill intensity is obviously endogenous, we use the average intensity of the last four years. Industry-level control variables such as exports and imports are from the OECD data base STAN (Standardized Analytical Database). Data for the countrylevel control variables, GDP and trade, is from the World Bank data base, World Development Indicators (WDI). See the Appendix for summary statistics and detailed information about data.

\section{Results}

\subsection{Country-level results}

\footnotetext{
${ }^{8}$ Australia, Canada, Denmark, Finland, France, Italy, Japan, Netherlands, Norway, Spain, Sweden, UK, USA and West Germany

${ }^{9}$ There is a strong positive rank correlation between our skill ranking measures and the implied industrylevel wage rate (calculated as total labor compensation divided by total employment) for all countries in the sample. Since education levels and wages are highly correlated, this suggests that our reliance on US skill data is relatively unproblematic.
} 
The estimates of equation 3.1 are presented in Table 1. It is clear that no evidence of a relationship between the supply of human capital and SBTC can be found. If anything, there is a negative (but not statistically significant) partial correlation between the supply of human capital and the rate of SBTC.

\section{[Table1 here]}

Several versions of the specifications in Table 1 have been tried. We have run regressions using the share of the population above 25 with higher education as an indicator of human capital. Lagged values of human capital have been used, as have changes in the supply of human capital. There are no statistically significant effects of human capital on SBTC in any of these specifications. ${ }^{10}$ Even if the number of observations is low, these results offer strong evidence against the hypothesis that the supply of human capital has lead to an increase in the rate of SBTC.

\subsection{Industry-level results}

As mentioned earlier, it is not possible to study the aggregate effect of human capital on $R \& D$ spending, since we are likely to pick up changes in industry structures across countries. Instead, we investigate whether the supply of human capital increases the R\&D intensity within industries. The first two columns of table 2 display the result from a cross-sectional study of 1980 and 1990. When only controlling for industry-skill intensity, the supply of human capital has a positive impact on industry R\&D intensity. However, when adding the control variables, the effect is no longer statistically significant. In the fifth and sixth column, we use lagged levels of human capital but there is still no effect. The last two columns show the results when exploiting the time dimension in the data. Controlling for country-industry effects, there is a positive impact of human capital on industry R\&D intensity. In sum, there seem to be some positive effects of the supply of human capital on industry-level R\&D intensity.

\footnotetext{
${ }^{10}$ These results are available upon request.
} 
Some interesting results are uncovered for the control variables. Unsurprisingly, more skill intensive industries do relatively more R\&D, but perhaps more interestingly, changes in skill intensity have no effect on $R \& D$. There is no evidence that globalization pressures induce more $R \& D$, since Trade has a negative effect on industry R\&D intensity in the cross-sectional study and there is no impact of any of the trade related variables in the panel.

\section{[Table 2]}

In Table 3, the results from industry-level regressions (equation 3.2) are shown. All regressions are run for the 1970's and the 1980's, respectively. In the first two columns, industry, but not country, fixed effects are used. In columns three and four, industry-level export and import ratios are included. In the next four columns, both industry and country fixed effects are included, and in the last two columns, industry-level controls are once more included.

\section{[Table 3]}

The results are highly consistent across specifications. First of all, during the 1980's, but not the 1970's, SBTC was mainly been present in skill-intensive sectors. This is in line with Haskel and Slaughter (2002), who find that SBTC was biased towards skill-intensive sectors in the 1980 's.

Second, the interaction between human capital and skill intensity is negative and statistically significant for the 1980's regressions. This means that the rate of SBTC in high-skilled relative to low-skill industries was relatively low in countries with high levels of human capital. The relative size of the negative interaction effect to the positive direct effect of skill-intensity on SBTC tells us that SBTC is negative, when total years of schooling is larger than about 6.5. This is true for most countries in the sample. In other words, there is a clear indication that high levels of human capital caused SBTC to be particularly biased towards low-skill industries, at least during the 1980's. 
Finally, there is no support for the idea that SBTC was more pronounced in countries with large stocks of human capital.

According to Theoning and Verdier (2003), globalization increases the threat of imitation and leapfrogging which could result in SBTC. Our results on exports, imports and aggregate international trade do not offer any clear support for these predictions.

Now, we turn to our second measure of SBTC - R\&D intensity. The results presented in table 4 first show the cross-sectional results and then the pooled data when we control for industry-country specific effects. Since yearly variations in all variables tend to be small, we use data on every fourth year. According to the results in the first two columns, industries in countries with more human capital have a higher R\&D intensity. For 1990, it also seems like this effect is greater for industries intensive in low-skilled workers. In fact, there is no effect of human capital for industries with the highest skill intensities. Including control variables weakens the effect of human capital and the effect is no longer statistically significant in 1990. The asymmetry between high- and low-skilled intensive sectors remains, which is confirmed in the panel regressions presented in the last two columns. When a country has a high supply of human capital, industries in this country will increase their spending on R\&D. However, the effect is most pronounced in low-skilled intensive industries. For example, the results presented in the last column imply that the effect of an increase in the supply of human capital is zero or negative for industries in the 95th percentile of the skill-intensity distribution. Including industry exports and imports, country-level GDP per capita or trade does not change the result. We have also run all regressions using lagged levels of human capital and with industry and/or country dummies, and the results are very similar to those presented in the table. ${ }^{11}$

[Table 4 here]

\footnotetext{
${ }^{11}$ Naturally available upon request.
} 
Next, we study the effect of changes in human capital on the level and direction of technical change, as measure by $R \& D$ intensity. Notice that changes are annualized to ensure comparability across specifications. The first two columns show the change in human capital to be positively related to the level of R\&D intensity in 1980 but not significantly so in 1990. As can be seen in the last column, there is no effect of changes in the supply of human capital on R\&D-intensity when pooling the data and controlling for country-industry effects.

[Table 5 here]

We have also investigated whether the supply of human capital affects SBTC and R\&D intensity asymmetrically in some other dimensions. Instead of skill intensity, we have used industry labor intensity, but we find no significant effects. Thus, the supply of human capital does not have a different effect on SBTC in industries with low labor intensity, as compared to those with high labor intensity.

\section{Conclusion}

It has been suggested that the supply of human capital has an impact on industry-level technical choice (Acemoglu, 2002b). In particular, Acemoglu argues that a high supply of human capital will increase the rate of SBTC. This paper has aimed at empirically investigating whether this hypothesis finds any support in the data. We find $R \& D$ to be positively related to the supply of human capital. There is, however, no indication that this translates into higher rates of SBTC, when SBTC is measured as changes in the wage bill share of skilled labor.

Some asymmetries between different industries have also been uncovered. While SBTC in general is biased towards skill-intensive industries, this effect is less pronounced in countries with a high supply of human capital. These findings are interesting, not the 
least in light of Haskel and Slaughter (2002), who find that wage inequality tends to increase when SBTC is biased towards skill-intensive industries.

Since Acemoglu's model does not discriminate between sector- and factor-biased technical change, it is hard to relate the results on sector biases to his framework. An alternative explanation to our findings would be that a large supply of human capital reduces the cost of $R \& D$. To the extent that the demand for $R \& D$ is more elastic in lowskill industries, our results on sector bias can be rationalized by such a cost-based explanation. We cannot, however, discriminate between these hypotheses and thus, leave this attempt to future research. 


\section{References}

Acemoglu, D. (2002a) “Technical Change, Inequality, and the Labor Market”, Journal of Economic Literature 40:1, 7-72.

Acemoglu, D. (2002b) "Directed Technical Change", Review of Economic Studies 69:4, 781-809.

Acemoglu, D. (2003) "Cross-Country Inequality Trends", Economic Journal 113:485, F121-49.

Autor, D., Katz, L., Krueger, A. (1998) "Computing Inequality: Have Computers Changed the Labor Market?”, Quarterly Journal of Economics 113:4, 1169-1213.

Autor, D., Katz, L (2000) "Changes in the Wage Structure and Earnings Inequality", in O. Ashenfelter and D. Card (eds.) The Handbook of Labor Economics Volume III, Amsterdam: Elsevier.

Berman, E., Bound, J., Machin, S. (1998) "Implications of Skill-Biased Technological Change: International Evidence”, Quarterly Journal of Economics 113:4, 1245-80.

Berndt, E.R., Wood, D.O., (1982) "The Specification and Measurement of Technical Change in U.S Manufacturing", In: Advances in the Economics of Energy and Resources, Vol 4. JAI Press, 199-221.

Binswanger, H.P. (1974) "The Measurement of Technical Change Bias with many Factors of Production”, American Economic Review 64, 964-976.

Card, D. and J. DiNardo (2002) "Skill-Biased Technological Change and Rising Wage Inequality: Some Problems and Puzzles", Journal of Labor Economics 20:4, 733-783.

Doms, M., Dunne, T., Troske, K. (1997) “Workers, Wages and Technology”, Quarterly Journal of Economics 112:1, 253-290.

Freeman, R. (1986) "Demand for Education" in O.Ashenfelter and R. Layard (eds.), Handbook of Labor Economics, Vol. 1, Amsterdam: North-Holland.

Gottschalk, P., Smeeding, T. (1997) "Cross-National Comparisons of Earnings and Income Inequality”, Journal of Economic Literature 37:2, 633-87.

Griliches, Z., Hall, B., Pakes, A. (1991) "R\&D, Patents an Market Values Revisited: Is There a Second (Technological Opportunity) Factor?" Economics of Innovation and New Technology, I 183-202. 
Habakkuk, J. (1962) American and British Technology in the Nineteenth Century: Search for Labour Saving Inventions, Cambridge: Cambridge University Press.

Haskel J., Slaughter, M. (2002) "Does the Sector Bias of Skill-Biased Technical Change Explain Changing Skill Premia?” European Economic Review 46, 1756-1783.

Hicks, J.(1932) The Theory of Wages, London: Macmillan.

Kennedy, C. (1964) "Induced Bias in Innovation and the Theory of Distribution", Economic Journal 74, 541-47.

Lawrence, R. and M. Slaughter (1993) "International Trade and American Wages in the 1980's: Giant Sucking Sound or Small Hiccup?", Brookings Papers on Economic Activity: Microeconomics, no. 2, 161-211.

Machin, S., Van Reenen, J. (1998) “ Technology and Changes in Skill Structure:

Evidence from Seven Countries”, Quarterly Journal of Economics 113:4, 1215-1244.

Maurin, E., Thesmar, D., Thoenig, M. (2002) "Globalization and the Demand for Skill: An Export Based Channel” Working paper CEPR no 3406.

Ruttan, V. (2001) Technology, Growth and Development: An Induced Innovation Interpretation, New York: Oxford University Press.

Thoenig, M., Verdier, T. (2003) "A Theory of Defensive Skill-Biased Innovation and Globalization” American Economic Review 93:3, 709-728. 


\section{Appendix.}

\section{Detailed description and summary statistics for data used when studying changes in non-production worker wage share (tables 1 and 3 ).}

\begin{tabular}{|c|c|c|c|c|c|c|}
\hline & $\begin{array}{c}\text { Description } \\
\text { Industry-level variables }\end{array}$ & Obs & Mean & $\begin{array}{l}\text { Std. } \\
\text { Dev }\end{array}$ & Min & Max \\
\hline SBTC & $\begin{array}{l}\text { The change in non-production worker wage share } \\
\text { Source: UNIDO }\end{array}$ & 680 & 0.26 & 0.62 & -3.16 & 3.43 \\
\hline Skillint & $\begin{array}{l}\text { Number of non-operational workers divided by the } \\
\text { number of operational workers. Source: UNIDO }\end{array}$ & 680 & 0.44 & 0.50 & 0.06 & 8.12 \\
\hline Dlwratio & $\begin{array}{l}\text { The decade long percentage change in the relative } \\
\text { wage of non-production to production workers in } \\
\text { total manufacturing. Source: UNIDO. }\end{array}$ & 680 & -0.05 & 0.21 & -1.13 & 1.18 \\
\hline Export & Exports as a share of production. Source: STAN & 680 & 0.22 & 0.242 & 0 & 2.492 \\
\hline Import & $\begin{array}{l}\text { Imports as a share of production. Source: STAN } \\
\text { Country-level variables }\end{array}$ & 680 & 0.39 & 0.69 & 0.001 & 10.064 \\
\hline $\mathrm{HC}$ & $\begin{array}{l}\text { Average schooling years in the total population } \\
\text { aged above } 25 \text {. The data is interpolated to annual } \\
\text { observations. Source: Barro and Lee }(2000)\end{array}$ & 27 & 8.377 & 2.046 & 2.99 & 11.941 \\
\hline Dlwratio & $\begin{array}{l}\text { The decade long percentage change in the relative } \\
\text { wage of non-production to production workers in } \\
\text { total manufacturing. Source: UNIDO. }\end{array}$ & 27 & -0.043 & 0.173 & -0.80 & 0.133 \\
\hline Trade & Trade in percent of GDP. Source: WDI. & 27 & 54.452 & 26.77 & 18.94 & 144.03 \\
\hline Gdppc & In US dollars. Source: WDI. & 27 & 17548 & 6168 & 4830 & 27800 \\
\hline
\end{tabular}

Values are for two ten-year periods (the 1970's and the 1980's). UNIDO stands for United Nation Industrial Statistics Data Base. STAN is the OECD Standardized Analytical Database. Barro-Lee data set is accessible on, for example, http://www.nuff.ox.ac.uk/Economics/Growth. WDI are the World Development Indicators from the World Bank. 


\section{Detailed description and summary statistics for data used when studying R\&D}

intensity (tables 2, 4 and 5).

\begin{tabular}{|c|c|c|c|c|c|c|}
\hline & $\begin{array}{l}\text { Description } \\
\text { Industry-level variables } \\
\end{array}$ & Obs & Mean & $\begin{array}{l}\text { Std. } \\
\text { Dev }\end{array}$ & Min & Max \\
\hline $\mathrm{R} \& \mathrm{D}$ & $\begin{array}{l}\text { R\&D spending as a share of production. Values } \\
<10^{-6} \text { are replaced by } 10^{-6} \text {. Values }>0.3 \text { are } \\
\text { replaced by } 0.3 \text {. Source: ANBERD }\end{array}$ & 1832 & 0.025 & 0.044 & 0 & 0.3 \\
\hline Skillint & $\begin{array}{l}\text { Share of people employed with at least some } \\
\text { college education. Average value the last four } \\
\text { years. Education intensities from US data. Source: } \\
\text { CPS }\end{array}$ & 1832 & 0.337 & 0.135 & 0.098 & 0.715 \\
\hline Export & Exports as a share of production. Source: STAN & 1803 & 0.354 & 0.446 & 0.005 & 6.226 \\
\hline \multirow[t]{2}{*}{ Import } & Imports as a share of production. Source: STAN & 1803 & 0.524 & 0.824 & 0.824 & 8.000 \\
\hline & Country-level variables & & & & & \\
\hline $\mathrm{HC}$ & $\begin{array}{l}\text { Average schooling years in the total population } \\
\text { aged above } 25 \text {. The data is interpolated to annual } \\
\text { observations. Source: Barro and Lee (2000) }\end{array}$ & 88 & 8.607 & 1.817 & 4.570 & 12.206 \\
\hline Trade & Trade as percent of GDP. Source: WDI. & 88 & 51.4 & 23.4 & 13.6 & 128.0 \\
\hline Gdppc & In US dollars. Source: WDI. & 88 & 19162 & 4703 & 9461 & 34504 \\
\hline
\end{tabular}

Values every fourth year (1973, 1977, 1981, 1985, 1989, 1993 and 1997). ANBERD is the OECD Business Enterprise R\&D data base. CPS is the Current Population Survey. STAN stands for the OECD Standardized Analytical Database. Barro-Lee data set is accessible on, for example, http://www.nuff.ox.ac.uk/Economics/Growth/barlee.htm. WDI is the World Bank World Development Indicators. 
Table 1. The supply of human capital and subsequent country-level SBTC.

\begin{tabular}{|c|c|c|c|c|c|c|}
\hline Dep var & SBTC & SBTC & SBTC & SBTC & SBTC & SBTC \\
\hline Period & 1970’s & 1980’s & 1970's & 1980’s & 1970’s & 1980's \\
\hline $\mathrm{HC}$ & $\begin{array}{r}-0.083 \\
(100)\end{array}$ & $\begin{array}{r}-0.035 \\
(0.90)\end{array}$ & $\begin{array}{r}-0.060 \\
(0.52)\end{array}$ & $\begin{array}{l}0.017 \\
(026)\end{array}$ & $\begin{array}{l}-0.184 \\
(114)\end{array}$ & $\begin{array}{l}-0.000 \\
(000)\end{array}$ \\
\hline Dlwratio & $\begin{array}{c}2.151 \\
(3.72)^{* * *}\end{array}$ & $\begin{array}{r}-0.463 \\
(0.30)\end{array}$ & $\begin{array}{c}2.228 \\
(4.45)^{* * *}\end{array}$ & $\begin{array}{l}-0.483 \\
(0.38)\end{array}$ & $\begin{array}{c}3.054 \\
(3.77)^{* * *}\end{array}$ & $\begin{array}{l}-0.807 \\
(0.63)\end{array}$ \\
\hline Gdppc & & & $\begin{array}{l}-0.000 \\
(0.67)\end{array}$ & $\begin{array}{l}-0.000 \\
(1.06)\end{array}$ & $\begin{array}{l}0.000 \\
(0.11)\end{array}$ & $\begin{array}{l}-0.000 \\
(0.92)\end{array}$ \\
\hline Trade & & & & & $\begin{array}{l}-0.009 \\
(1.54)\end{array}$ & $\begin{array}{l}-0.003 \\
(1.20)\end{array}$ \\
\hline Constant & $\begin{array}{l}1.202 \\
(1.78)\end{array}$ & $\begin{array}{c}0.739 \\
(2.10)^{*}\end{array}$ & $\begin{array}{c}1.276 \\
(2.11)^{*}\end{array}$ & $\begin{array}{c}0.685 \\
(2.08)^{*}\end{array}$ & $\begin{array}{c}2.583 \\
(2.19)^{*}\end{array}$ & $\begin{array}{c}0.948 \\
(2.26)^{*}\end{array}$ \\
\hline Observations & 14 & 13 & 14 & 13 & 14 & 13 \\
\hline R-squared & 0.54 & 0.07 & 0.56 & 0.18 & 0.64 & 0.24 \\
\hline
\end{tabular}


Table 2. Effect of human capital on industry R\&D intensity

\begin{tabular}{|c|c|c|c|c|c|c|c|c|}
\hline Dep var & LnR\&D & LnR\&D & LnR\&D & LnR\&D & LnR\&D & LnR\&D & LnR\&D & LnR\&D \\
\hline Period & 1980 & 1990 & 1980 & 1990 & 1980 & 1990 & 1973-98 & $1973-98$ \\
\hline $\mathrm{HC}$ & $\begin{array}{c}0.194 \\
(2.62)^{* *}\end{array}$ & $\begin{array}{l}0.114 \\
(2.08)^{*}\end{array}$ & $\begin{array}{l}0.104 \\
(1.28)\end{array}$ & $\begin{array}{l}0.021 \\
(0.31)\end{array}$ & & & $\begin{array}{c}0.178 \\
(3.02)^{* * *}\end{array}$ & $\begin{array}{c}0.132 \\
(1.92)^{*}\end{array}$ \\
\hline Lag HC & & & & & $\begin{array}{c}0.173 \\
(1.69)\end{array}$ & $\begin{array}{l}0.083 \\
(1.26)\end{array}$ & & \\
\hline Skillint & $\begin{array}{c}8.578 \\
(9.97)^{* * *}\end{array}$ & $\begin{array}{c}7.804 \\
(15.20)^{* * *}\end{array}$ & $\begin{array}{c}8.373 \\
(10.62)^{* * *}\end{array}$ & $\begin{array}{c}7.232 \\
(16.66)^{* * *}\end{array}$ & $\begin{array}{c}8.583 \\
(9.99)^{* * *}\end{array}$ & $\begin{array}{c}7.805 \\
(15.21)^{* * *}\end{array}$ & $\begin{array}{l}-0.691 \\
(1.15)\end{array}$ & $\begin{array}{l}-0.830 \\
(1.35)\end{array}$ \\
\hline Gdppc & & & $\begin{array}{c}0.000 \\
(1.86)^{*}\end{array}$ & $\begin{array}{c}0.000 \\
(3.00)^{* *}\end{array}$ & & & & $\begin{array}{l}0.000 \\
(1.55)\end{array}$ \\
\hline Trade & & & $\begin{array}{c}-0.018 \\
(5.31)^{* * *}\end{array}$ & $\begin{array}{c}-0.020 \\
(9.93)^{* * *}\end{array}$ & & & & $\begin{array}{l}-0.005 \\
(0.75)\end{array}$ \\
\hline Export & & & $\begin{array}{c}2.119 \\
(7.22)^{* * *}\end{array}$ & $\begin{array}{c}0.726 \\
(3.17)^{* * *}\end{array}$ & & & & $\begin{array}{l}0.458 \\
(1.59)\end{array}$ \\
\hline Import & & & $\begin{array}{c}-0.566 \\
(2.18)^{* *}\end{array}$ & $\begin{array}{l}-0.047 \\
(0.21)\end{array}$ & & & & $\begin{array}{l}-0.105 \\
(0.54)\end{array}$ \\
\hline $\begin{array}{l}\text { Time FE } \\
\text { Country- } \\
\text { industry FE }\end{array}$ & & & & & & & $\begin{array}{l}\text { Yes } \\
\text { Yes }\end{array}$ & $\begin{array}{l}\text { Yes } \\
\text { Yes }\end{array}$ \\
\hline Constant & $\begin{array}{c}-9.457 \\
(12.43)^{* * *}\end{array}$ & $\begin{array}{c}-8.770 \\
(14.79)^{* * *}\end{array}$ & $\begin{array}{c}-9.646 \\
(12.86)^{* * *}\end{array}$ & $\begin{array}{c}-8.509 \\
(13.54)^{* * *}\end{array}$ & $\begin{array}{c}-9.188 \\
(9.74)^{* * *}\end{array}$ & $\begin{array}{c}-8.455 \\
(12.50)^{* * *}\end{array}$ & & \\
\hline Observations & 305 & 305 & 305 & 305 & 305 & 305 & 1832 & 1803 \\
\hline $\mathrm{R}$-squared & 0.28 & 0.32 & 0.35 & 0.38 & 0.27 & 0.32 & 0.91 & 0.91 \\
\hline
\end{tabular}

Significance at the $1(*), 5(* *)$ and $10(* * *)$ percent level is indicated. Standard errors are clustered at the country level in column (1)-(6) and country-year in the two last columns. 
Table 3. Effects of human capital on SBTC.

\begin{tabular}{|c|c|c|c|c|c|c|c|c|}
\hline Dep var & SBTC & SBTC & SBTC & SBTC & SBTC & SBTC & SBTC & SBTC \\
\hline Period & 1970’s & 1980’s & 1970's & 1980's & 1970's & 1980’s & 1970’s & 1980’s \\
\hline $\mathrm{HC}$ & $\begin{array}{l}-0.091 \\
(1.53)\end{array}$ & $\begin{array}{l}-0.018 \\
(0.52)\end{array}$ & $\begin{array}{l}-0.123 \\
(1.50)\end{array}$ & $\begin{array}{l}-0.075 \\
(1.12)\end{array}$ & & & & \\
\hline Skillint & $\begin{array}{l}0.014 \\
(0.01)\end{array}$ & $\begin{array}{l}0.624 \\
(2.51)^{* *}\end{array}$ & $\begin{array}{l}-0.101 \\
(0.11)\end{array}$ & $\begin{array}{l}0.669 \\
(2.93)^{* *}\end{array}$ & $\begin{array}{l}-0.201 \\
(0.21)\end{array}$ & $\begin{array}{l}0.548 \\
(2.60)^{* *}\end{array}$ & $\begin{array}{l}-0.176 \\
(0.19)\end{array}$ & $\begin{array}{l}0.535 \\
(2.50)^{* *}\end{array}$ \\
\hline Skillint $\times \mathrm{HC}$ & $\begin{array}{l}-0.006 \\
(0.05)\end{array}$ & $\begin{array}{l}-0.103 \\
(2.62)^{* *}\end{array}$ & $\begin{array}{l}0.013 \\
(0.11)\end{array}$ & $\begin{array}{l}-0.109 \\
(2.96)^{* *}\end{array}$ & $\begin{array}{l}0.044 \\
(0.37)\end{array}$ & $\begin{array}{l}-0.095 \\
(2.82)^{* *}\end{array}$ & $\begin{array}{l}0.040 \\
(0.38)\end{array}$ & $\begin{array}{l}-0.093 \\
(2.73)^{* *}\end{array}$ \\
\hline Dlwratio & $\begin{array}{l}0.748 \\
(3.95)^{* * *}\end{array}$ & $\begin{array}{l}0.643 \\
(3.16)^{* * *}\end{array}$ & $\begin{array}{l}0.702 \\
(3.90)^{* * *}\end{array}$ & $\begin{array}{l}0.535 \\
(2.41)^{* *}\end{array}$ & $\begin{array}{l}0.480 \\
(4.55)^{* * *}\end{array}$ & $\begin{array}{l}0.695 \\
(2.92)^{* *}\end{array}$ & $\begin{array}{l}0.457 \\
(4.16) * * *\end{array}$ & $\begin{array}{l}0.702 \\
(3.00)^{* *}\end{array}$ \\
\hline Gdppc & & & $\begin{array}{l}0.000 \\
(0.10)\end{array}$ & $\begin{array}{l}0.000 \\
(0.85)\end{array}$ & & & & \\
\hline Trade & & & $\begin{array}{l}-0.003 \\
(0.79)\end{array}$ & $\begin{array}{l}-0.006 \\
(1.79)^{*}\end{array}$ & & & & \\
\hline Exports & & & $\begin{array}{l}0.030 \\
(0.20)\end{array}$ & $\begin{array}{l}0.006 \\
(0.03)\end{array}$ & & & $\begin{array}{l}-0.070 \\
(0.47)\end{array}$ & $\begin{array}{l}-0.065 \\
(0.30)\end{array}$ \\
\hline Imports & & & $\begin{array}{l}-0.049 \\
(0.56)\end{array}$ & $\begin{array}{l}-0.018 \\
(0.52)\end{array}$ & & & $\begin{array}{l}-0.053 \\
(0.62)\end{array}$ & $\begin{array}{l}-0.043 \\
(1.15)\end{array}$ \\
\hline Country FE & No & No & No & No & Yes & Yes & Yes & Yes \\
\hline Industry FE & Yes & Yes & Yes & Yes & Yes & Yes & Yes & Yes \\
\hline Observations & 355 & 347 & 333 & 347 & 355 & 347 & 355 & 347 \\
\hline R-squared & 0.60 & 0.26 & 0.62 & 0.26 & 0.67 & 0.36 & 0.67 & 0.36 \\
\hline
\end{tabular}

Significance at the $1(*), 5(* *)$ and $10(* * *)$ percent level is indicated. Standard errors are clustered at the country level. 
Table 4. Effects of human capital on R\&D intensity.

\begin{tabular}{|c|c|c|c|c|c|c|}
\hline Dep var & LnR\&D & LnR\&D & LnR\&D & LnR\&D & LnR\&D & LnR\&D \\
\hline Period & 1980 & 1990 & 1980 & 1990 & $1973-98$ & $1973-98$ \\
\hline $\mathrm{HC}$ & $\begin{array}{c}0.417 \\
(2.53)^{* *}\end{array}$ & $\begin{array}{c}0.343 \\
(3.25)^{* * *}\end{array}$ & $\begin{array}{c}0.328 \\
(1.90)^{*}\end{array}$ & $\begin{array}{l}0.244 \\
(1.63)\end{array}$ & $\begin{array}{c}0.367 \\
(4.10)^{* * *}\end{array}$ & $\begin{array}{c}0.324 \\
(3.09)^{* * *}\end{array}$ \\
\hline Skillint & $\begin{array}{c}14.476 \\
(3.98)^{* * *}\end{array}$ & $\begin{array}{c}13.147 \\
(6.57)^{* * *}\end{array}$ & $\begin{array}{c}14.318 \\
(4.54)^{* * *}\end{array}$ & $\begin{array}{c}12.413 \\
(5.40)^{* * *}\end{array}$ & $\begin{array}{c}4.641 \\
(3.06)^{* * *}\end{array}$ & $\begin{array}{c}4.545 \\
(3.15)^{* * *}\end{array}$ \\
\hline Skillint $\times \mathrm{HC}$ & $\begin{array}{c}-0.703 \\
(1.68)\end{array}$ & $\begin{array}{c}-0.584 \\
(2.50)^{* *}\end{array}$ & $\begin{array}{c}-0.707 \\
(1.94)^{*}\end{array}$ & $\begin{array}{c}-0.565 \\
(2.12)^{*}\end{array}$ & $\begin{array}{c}-0.537 \\
(2.96)^{* * *}\end{array}$ & $\begin{array}{c}-0.549 \\
(3.18)^{* * *}\end{array}$ \\
\hline Gdppc & & & $\begin{array}{c}0.000 \\
(1.86)^{*}\end{array}$ & $\begin{array}{c}0.000 \\
(2.98)^{* *}\end{array}$ & & $\begin{array}{c}0.000 \\
(2.13)^{* *}\end{array}$ \\
\hline Trade & & & $\begin{array}{c}-0.018 \\
(5.19)^{* * *}\end{array}$ & $\begin{array}{c}-0.020 \\
(9.94)^{* * *}\end{array}$ & & $\begin{array}{l}-0.003 \\
(0.54)\end{array}$ \\
\hline Export & & & $\begin{array}{c}2.120 \\
(7.04)^{* * *}\end{array}$ & $\begin{array}{c}0.743 \\
(3.37)^{* * *}\end{array}$ & & $\begin{array}{c}0.519 \\
(1.79)^{*}\end{array}$ \\
\hline Import & & & $\begin{array}{c}-0.580 \\
(2.23)^{* *}\end{array}$ & $\begin{array}{l}-0.065 \\
(0.30)\end{array}$ & & $\begin{array}{l}-0.128 \\
(0.66)\end{array}$ \\
\hline $\begin{array}{l}\text { Time FE } \\
\text { Country- } \\
\text { industry FE }\end{array}$ & & & & & $\begin{array}{l}\text { Yes } \\
\text { Yes }\end{array}$ & $\begin{array}{l}\text { Yes } \\
\text { Yes }\end{array}$ \\
\hline Constant & $\begin{array}{c}-11.326 \\
(7.79)^{* * *}\end{array}$ & $\begin{array}{c}-10.868 \\
(11.17)^{* * *}\end{array}$ & $\begin{array}{c}-11.532 \\
(8.17)^{* * *}\end{array}$ & $\begin{array}{c}-10.545 \\
(9.06)^{* * *}\end{array}$ & & \\
\hline Observations & 305 & 305 & 305 & 305 & 1832 & 1803 \\
\hline R-squared & 0.28 & 0.33 & 0.35 & 0.38 & 0.91 & 0.91 \\
\hline
\end{tabular}


Table 5. Effects of changes of human capital on R\&D intensity.

\begin{tabular}{|c|c|c|c|}
\hline Dep var & LnR\&D & LnR\&D & LnR\&D \\
\hline Period & $\begin{array}{c}1980 \\
\text { eight-year } \\
\text { changes }\end{array}$ & $\begin{array}{c}1990 \\
\text { eight-year } \\
\text { changes }\end{array}$ & $\begin{array}{c}1973-98 \\
\text { four-year } \\
\text { changes }\end{array}$ \\
\hline$\Delta \mathrm{HC}$ & $\begin{array}{c}8.632 \\
(2.16)^{*}\end{array}$ & $\begin{array}{l}1.169 \\
(0.68)\end{array}$ & $\begin{array}{r}-0.283 \\
(0.32)\end{array}$ \\
\hline Skillint & $\begin{array}{c}9.357 \\
(5.78)^{* * *}\end{array}$ & $\begin{array}{c}7.997 \\
(12.39)^{* * *}\end{array}$ & $\begin{array}{l}-1.114 \\
(1.47)\end{array}$ \\
\hline Skillint $\times \Delta \mathrm{HC}$ & $\begin{array}{l}-8.530 \\
(0.83)\end{array}$ & $\begin{array}{l}-2.851 \\
(0.80)\end{array}$ & $\begin{array}{l}3.313 \\
(1.48)\end{array}$ \\
\hline$\Delta$ Export & $\begin{array}{l}-4.152 \\
(0.54)\end{array}$ & $\begin{array}{l}-4.741 \\
(1.10)\end{array}$ & $\begin{array}{l}0.107 \\
(0.10)\end{array}$ \\
\hline$\Delta$ Import & $\begin{array}{l}0.155 \\
(0.10)\end{array}$ & $\begin{array}{l}5.200 \\
(1.60)\end{array}$ & $\begin{array}{l}-0.747 \\
(0.84)\end{array}$ \\
\hline$\Delta$ Trade & $\begin{array}{l}0.134 \\
(0.42)\end{array}$ & $\begin{array}{l}0.204 \\
(1.07)\end{array}$ & $\begin{array}{l}-0.020 \\
(0.95)\end{array}$ \\
\hline$\Delta \mathrm{Gdppc}$ & $\begin{array}{l}0.000 \\
(0.09)\end{array}$ & $\begin{array}{c}0.004 \\
(4.40)^{* * *}\end{array}$ & $\begin{array}{l}0.000 \\
(0.50)\end{array}$ \\
\hline $\begin{array}{l}\text { Time FE } \\
\text { Industry-country } \\
\text { FE }\end{array}$ & & & $\begin{array}{l}\text { Yes } \\
\text { Yes }\end{array}$ \\
\hline Constant & $\begin{array}{c}-8.866 \\
(10.07)^{* * *}\end{array}$ & $\begin{array}{c}-9.736 \\
(16.01)^{* * *}\end{array}$ & \\
\hline $\begin{array}{l}\text { Observations } \\
\text { R-squared }\end{array}$ & $\begin{array}{l}297 \\
0.29\end{array}$ & $\begin{array}{l}305 \\
0.36\end{array}$ & $\begin{array}{l}1498 \\
0.93\end{array}$ \\
\hline
\end{tabular}

Significance at the $1(*), 5(* *)$ and $10(* * *)$ percent level is indicated. Standard errors are clustered on country in columns one and two, and on country-year in column three. Four-years means changes in the variables in the last four years. Eight-years means changes in the variables in the last eight years. All changes have been annualized for comparability across specifications. 